\begin{tabular}{|c|c|c|}
\hline $\begin{array}{l}\text { OPEN ACCESS } \\
\text { Vol. } 4 \text { No. 1: 20-27 } \\
\text { Tahun 2020 } \\
\text { Artikel penelitian 居 }\end{array}$ & $\begin{array}{c}\text { Durreal Alkwatililestatri } \\
\text { E-ISSN: 2598-8204 } \\
\text { http://ojs.umrah.ac.id/index.php/akuatiklestari } \\
\text { DOI: https://doi.org/10.31629/akuatiklestari.v4i1.2486 }\end{array}$ & $Q=$ \\
\hline
\end{tabular}

\title{
Makrozoobentos sebagai Bioindikator Kualitas Perairan di Senggarang Besar Kota Tanjungpinang
}

\author{
Macrozoobentos as a Bioindicator of Water Quality in Senggarang Besar, Tanjungpinang City
}

Raden Aditiyarma Putra ${ }^{1 \bowtie}$, Winny Retna Melani' ${ }^{1}$, Ani Suryanti ${ }^{2,3}$

1Manajemen Sumberdaya Perairan, Fakultas Ilmu Kelautan dan Perikanan, Universitas Maritim Raja Ali Haji, Tanjungpinang, Indonesia 29111

2Sosial Ekonomi Perikanan, Fakultas Ilmu Kelautan dan Perikanan, Universitas Maritim Raja Ali Haji, Tanjungpinang, Indonesia 29111

3Magister Ilmu Lingkungan, Universitas Maritim Raja Ali Haji, Indonesia 29111

У Info Artikel:

Diterima: 24 Agustus 2020

Revisi: 12 September 2020

Disetujui: 10 November 2020

Dipublikasi: 30 November 2020

Keyword:

makrozoobentos, bioindikator, kualitas

perairan, $\mathrm{FBI}$

$\square$ Penulis Korespondensi:

Raden Aditiyarma Putra

Manajemen Sumberdaya Perairan, Fakultas

IImu Kelautan dan Perikanan, Universitas

Maritim Raja Ali Haji

Email: radenaditp@gmail.com
ABSTRAK. Makrozoobentos merupakan organisme yang peka terhadap perubahan lingkungan sehingga sangat baik digunakan sebagai indikator biologis suatu perairan. Penelitian ini bertujuan untuk mengetahui jenis makrozoobentos, tingkat keanekaragaman, keseragaman, dominansi makrozoobentos dan kualitas perairan Senggarang Besar berdasarkan keberadaan makrozoobentos (menggunakan Family Biotic Index). Penelitian menggunakan metode survei. Penentuan stasiun menggunakan metode purposive sampling. Pengambilan sampel makrozoobentos menggunakan line transect dengan transek kuadrat dan core sampler. Makrozoobentos yang ditemukan di Perairan Senggarang Besar yaitu: Anadara granosa, Canarium urceus, Capitella teleta, Cerithium coralium, Nerita ritena, Luidia columbia, Tapes literatus, Nassarius olivaceus, Pirenella cingulata, Planaxis sulcatus, Polymesoda erosa, Pythia scarabaeus, Semiricinula tissoti, dan Terebralia sulcata. Keanekaragaman tertinggi terdapat pada stasiun $2\left(H^{\prime}=1,91\right)$ dan makrozoobentos yang mendominasi dari famili Certhiidae. Keseragaman tertinggi terdapat pada stasiun $3(E=0,94)$ dan makrozoobentos yang mendominasi dari famili Potamididae. Dominansi tertinggi terdapat pada stasiun $1(C=0,52)$ dan makrozoobentos yang mendominasi dari famili Potamididae dan Cerithiidae. Dari keseluruhan parameter fisika-kimia, parameter nitrat dan fosfat tidak memenuhi baku mutu berdasarkan KepMen LH No.51 Tahun 2004 untuk biota laut. Kualitas perairan Senggarang Besar berdasarkan makrozoobentos sebagai bioindikator didapatkan bahwa, stasiun $1(\mathrm{FBI}=6,94)$ dengan kategori buruk, stasiun $2(\mathrm{FBI}=5,6)$ dengan kategori cukup, stasiun $3(\mathrm{FB}=7)$ dengan kategori buruk.

ABSTRACT. Macrozoobenthos is an organism that is sensitive to environmental changes, so it is very well used as a biological indicator of water. This study aims to determine the type of macrozoobenthos, the level of diversity, uniformity, dominance of macrozoobenthos and quality of Senggarang Besar waters based on the presence of macrozoobenthos (using the Family Biotic Index). This research uses a survey method. Determination of the station using purposive sampling method. Macrozoobenthic sampling using line trasnsect with quadratic transects and core sampler. Macrozoobenthos found in the waters of Senggarang Besar are Capitella teleta, Cerithium coralium, Nerita ritena, Luidia columbia, Tapes literatus, Nassarius olivaceus, Pirenella cingulata, Planaxis sulcatus, Polymesoda erosa, Pythia scarabaeus, Semiricinula tissoti, and Terebralia sulcata. The highest diversity was found at station 2 ( $\mathrm{H}$ '= 1.91) and macrozoobenthos, which dominated the Certhiidae family. The highest uniformity was found at station $3(E=0.94)$ and macrozoobenthos, which dominated the Potamididae family. The highest dominance was at station $1(C=0.52)$ and macrozoobenthos, which dominated the Potamididae and Cerithiidae families. Of all the physico-chemical parameters, the nitrate and phosphate parameters do not meet the quality standards based on the Minister of Environment Decree No.51 of 2004 for marine biota. The quality of Senggarang Besar waters is based on macrozoobenthos as a bioindicator, station $1(\mathrm{FBI}=6.94)$ is in a bad category, station $2(\mathrm{FBI}=5.6)$ is in a sufficient category, station $3(\mathrm{FBI}=7)$ is in a bad category.

篔 How to cite this article:

Putra, R.A., Melani, R.M., \& Suryanti, A. (2020). Makrozoobentos sebagai Bioindikator Kualitas Perairan di Senggarang Besar Kota Tanjungpinang . Jurnal Akuatiklestari, 4(1): 20-27. DOI: https://doi.org/10.31629/akuatiklestari.v4i1.2486 


\section{PENDAHULUAN}

Senggarang Besar memiliki potensi sumberdaya alam berupa vegetasi (mangrove), biota (ikan) maupun sumberdaya mineral (bauksit) yang dimanfaatkan oleh masyarakat sebagai sumber mata pencaharian. Kawasan permukiman Senggarang Besar yang terletak sangat dekat dengan bibir pantai memungkinkan adanya buangan limbah domestik ke dalam perairan dan dapat mempengaruhi kualitas perairan. Wilayah perairan Senggarang Besar juga dimanfaatkan warga setempat sebagai jalur transportasi laut.

Kawasan Senggarang Besar terdapat sejumlah lahan terbuka akibat aktivitas pasca penambangan. Lahan terbuka yang berhubungan langsung ke perairan berpotensi terhadap perubahan kualitas perairan dan pertumbuhan biota yang hidup di dalamnya, khususnya makrozoobentos. Penurunan terhadap kelimpahan dan komposisi organisme makrozoobentos dapat digunakan sebagai indikator adanya gangguan ekologi yang terjadi pada suatu perairan, (Oktarina \& Syamsudin, 2015).

Makrozoobentos sebagai bioindikator berkaitan dengan faktor-faktor lingkungan perairan seperti kecerahan yang berpengaruh terhadap suhu perairan, kandungan unsur kimia seperti kandungan ion hidrogen $(\mathrm{pH})$, Oksigen terlarut (DO), TSS, BOD dan COD (Lubis et al., 2013). Penelitian ini bertujuan untuk mengetahui jenis makrozoobentos, tingkat keanekaragaman, keseragaman, dominansi makrozoobentos dan kualitas perairan Senggarang Besar berdasarkan keberadaan makrozoobentos (menggunakan Family Biotic Index).

\section{BAHAN DAN METODE}

Metode yang digunakan dalam pengambilan data makrozoobentos adalah metode line transect. Tiap stasiun di tarik jarak $20 \mathrm{~m}$ dari garis pantai ke titik awal stasiun pengamatan. Tiap stasiun terdiri dari 3 titik pengamatan yang memiliki jarak $10 \mathrm{~m}$. Jadi, untuk 3 stasiun terdapat 9 titik pengamatan. Pengambilan sampel makrozoobentos epifauna dilakukan pada tiap stasiun menggunakan transek kuadrat yang berukuran $1 \mathrm{~m} \times 1 \mathrm{~m}$ dan sampel makrozoobentos infauna menggunakan core sampler dengan kedalaman $\pm 1,5 \mathrm{~m}$. Makrozoobentos epifauna, infauna dan substrat dimasukkan terlebih dahulu kedalam botol yang berisi alkohol 70\%, selanjutnya diidentifikasi di Laboraturium Fakultas Ilmu Kelautan dan Perikanan, Universitas Maritim Raja Ali Haji Kota Tanjungpinang, Provinsi Kepulauan Riau.

\subsection{Waktu dan Tempat}

Penelitian dilaksanakan pada Maret - Juli 2020, berlokasi di Perairan Senggarang Besar, Kelurahan Senggarang, Kecamatan Tanjungpinang Kota, Provinsi Kepulauan Riau. Lokasi Penelitian dapat dilihat pada Gambar 1.

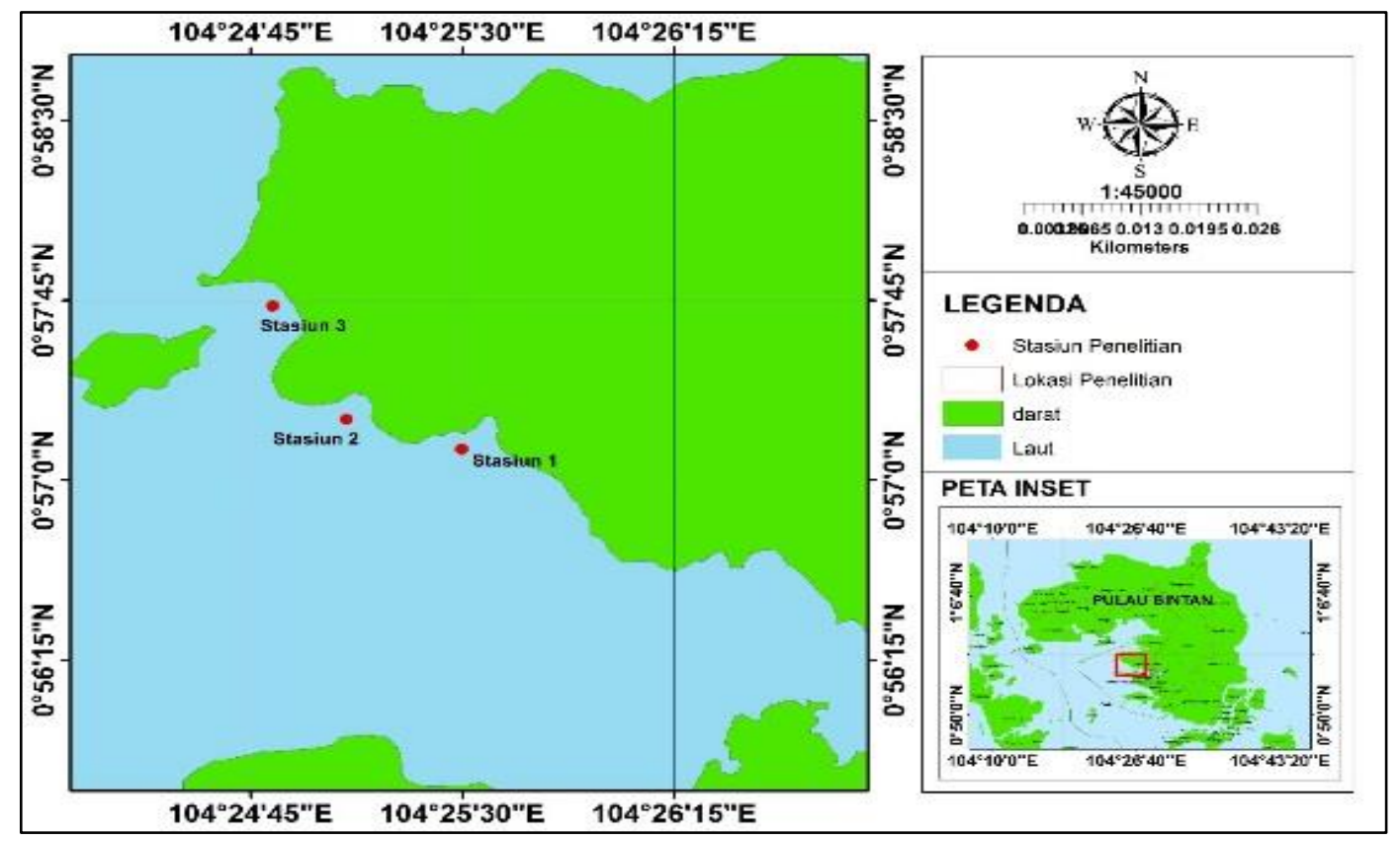

Gambar 1. Lokasi Penelitian

\subsection{Alat dan Bahan}

Alat-alat yang digunakan dalam penelitian ini meliputi GPS (menentukan titik koordinat penyamplingan), timbangan digital (menimbang sedimen), oven (mengeringkan substrat), ayakan (menyaring sedimen) Multi tester (mengukur Suhu, pH, DO) tali raffia (untuk mentransek garis) kantong plastik (untuk meletakkan sampel) kertas label (memberikan label tiap stasiun) cool box (Untuk menyimpan sampel sedimen dan biota) rose Bengal (pewarna) alcohol 70\% (Pengawetan sampel makrozoobentos). 


\subsection{Prosedur Penelitian}

\subsubsection{Teknik Pengumpulan Data}

Data yang diperoleh dari pengukuran fisika-kimia perairan selanjutnya dibandingkan dengan Kepmen LH No. 51 Tahun 2004 tentang baku mutu untuk biota laut. Data makrozoobentos yang telah diperoleh kemudian disajikan dalam bentuk tabel dan gambar. Data tersebut kemudian dianalisis secara deskriptif berdasarkan hasil dari penghitungan kelimpahan, indeks keanekaragaman, keseragaman, dominansi, dan FBI (Family Biotic Index) yang dihubungkan dengan karakteristik lapangan.

\subsection{Analisis Data}

\subsubsection{Kepadatan Makrozoobentos}

Makrozoobentos yang diperoleh kemudian dihitung kepadatannya dalam jumlah individu per satuan luas dan dikonversikan dalam satuan ind $/ \mathrm{m}^{2}$ dengan menggunakan rumus sebagai berikut (Efriningsih et al., 2016):

$$
D=\frac{Z}{A} \times 10.000
$$

Keterangan:

D : Jumlah individu persatuan luas (ind $/ \mathrm{Ha}$ )

Z : Jumlah individu dalam titik sampling

A $\quad$ : Luas titik sampling (m) (x 10.000 konversi $\mathrm{m}^{2}$ ke Ha)

\subsubsection{Keanekaragaman Makrozoobentos $\left(\mathrm{H}^{\prime}\right)$}

Keanekaragaman jenis makrozoobentos dihitung dengan Indeks Keanekaragaman Shannon - Wienner, (Efringingsih et al., 2016) dirumuskan sebagai berikut:

$$
\mathrm{H}^{\prime}=-\sum_{i=0}^{n} p i \ln p i
$$

Keterangan:

$\mathrm{H}^{\prime} \quad$ : Indeks keanekaragaman

$\mathrm{Ni} \quad$ :Jumlah individu masing-masing jenis

S : Jumlah spesies yang ditemukan

Kategori Indeks Keanekaragaman: Shannon dan Wienner

$\mathrm{H}<1 \quad:$ Keanekaragaman rendah

$1<\mathrm{H}^{\prime}<3:$ Keanekaragaman sedang

$\mathrm{H}^{\prime}<3$ : Keanekaragaman tinggi

\subsubsection{Keseragaman Makrozoobentos (E)}

Keseragaman dari suatu spesies dalam komunitas dapat diketahui Indeks Keseragaman Simpson (Efriningsih et al., 2016) yang dinyatakan sebagai:

$$
E=\frac{H^{\prime}}{\ln S}
$$

Keterangan:

$\begin{array}{ll}\mathrm{E} & \text { : Indeks keseragaman Evenness } \\ \mathrm{S} & \text { : Jumlah spesies } \\ \mathrm{H}^{\prime} & \text { : Indeks keanekaragaman }\end{array}$

Kategori Indeks Keseragaman: Simpson

$\mathrm{E}<0,4 \quad:$ rendah

$0,4<\mathrm{E}<0,6 \quad:$ sedang

$\mathrm{E}<0,6 \quad$ : tinggi

\subsubsection{Dominansi Makrozoobentos (C)}

Dominansi dari suatu spesies dalam komunitas dapat diketahui dari hasil analisis dengan menggunakan Indeks Dominansi Simpson (Efriningsih et al., 2016):

$$
C=\sum_{i=1}^{s}(\mathrm{ni} / \mathrm{N})^{2}
$$


Keterangan:

$\begin{array}{ll}\mathrm{C} & \text { : Indeks Dominansi Simpson } \\ \text { ni } & \text { : jumlah individu masing-masing jenis } \\ \mathrm{N} & \text { : jumlah semua individu tiap spesies }\end{array}$

Kategori Indeks Dominansi: Simpson

$0,00<C<0,50 \quad:$ rendah

$0,50<C<0,75 \quad:$ sedang

$0,75<C<1,00 \quad$ : tinggi.

\subsubsection{Famili Biotik Index (FBI)}

Famili Biotic Index (FBI) digunakan untuk mendeteksi pencemaran organik dan dasarnya adalah tingkatan famili yang toleran dan tidak toleran. Rumus yang digunakan untuk menghitung indeks ini sebagai berikut:

$$
F B I=\frac{(n i x t i)}{N}
$$

Keterangan:

FBI : nilai indeks makrozoobentos bentik

ni : jumlah individu kelompok famili ke-I,

$\mathrm{Ti} \quad$ : tingkat toleransi kelompok famili ke-I

$\mathrm{N} \quad$ : jumlah seluruh individu yang menyusun komunitas makrozoobentos.

Interpretasi kualitas perairan berdasarkan FBI disajikan pada Tabel 1.

Tabel 1. Interpretasi FBI untuk Menilai Kualitas Air

\begin{tabular}{ccl} 
Famili Biotik Indeks & Status Kualitas Air & \multicolumn{1}{c}{ Tingkat Pencemaran } \\
$0,00-3,75$ & Sangat baik & Tidak terpolusi bahan organik \\
$3,76-4,25$ & Baik sekali & Sedikit terpolusi bahan organik \\
$4,26-5,00$ & Baik & Terpolusi beberapa bahan organik \\
$5,01-5,75$ & Cukup & Terpolusi agak banyak bahan organik \\
$5,76-6,50$ & Agak buruk & Terpolusi banyak bahan organik \\
$6,51-7,25$ & Buruk & Terpolusi sangat banyak bahan organik \\
$7,26-10,00$ & Buruk sekali & Terpolusi berat bahan organik \\
\hline
\end{tabular}

Sumber: Dwitawati et al. (2015)

\section{HASIL DAN PEMBAHASAN}

3.1. Parameter Fisika dan Kimia Perairan di Senggarang Besar

Hasil pengukuran parameter fisika dan kimia perairan di Senggarang Besar disajikan pada Tabel 2.

Tabel 2. Hasil Pengukuran Parameter Fisika-kimia Perairan

\begin{tabular}{|c|c|c|c|c|c|c|}
\hline No & Parameter & Satuan & Stasiun 1 & $\begin{array}{c}\text { Nilai } \\
\text { Stasiun } 2\end{array}$ & Stasiun 3 & Baku Mutu* \\
\hline \multirow[t]{6}{*}{1} & Fisika & & & & & \\
\hline & Suhu & ${ }^{0} \mathrm{C}$ & $30 \pm 0,2$ & $29,9 \pm 0,1$ & $30,17 \pm 0,6$ & $28-32$ \\
\hline & Kecerahan & $\mathrm{m}$ & $1,08 \pm 0,04$ & $0,94 \pm 0,03$ & $0,96 \pm 0,02$ & - \\
\hline & Salinitas & $\%$ & $24,67 \pm 1,5$ & $24,10 \pm 2,3$ & $23,73 \pm 1,1$ & $33-34$ \\
\hline & TSS & $\mathrm{mg} / \mathrm{L}$ & $5,16 \pm 0,2$ & $4,31 \pm 0,2$ & $4,56 \pm 0,2$ & 80 \\
\hline & Substrat & - & Pasir & Pasir & Pasir & - \\
\hline \multirow[t]{8}{*}{2} & Kimia & & & & & \\
\hline & $\mathrm{pH}$ & - & $7,29 \pm 0,1$ & $7,37 \pm 0,5$ & $7,23 \pm 0,2$ & $7-8,5$ \\
\hline & DO & $\mathrm{mg} / \mathrm{L}$ & $6,9 \pm 0,2$ & $6,6 \pm 0,2$ & $6,87 \pm 0,6$ & $>5$ \\
\hline & $\mathrm{BOD}_{5}$ & $\mathrm{mg} / \mathrm{L}$ & $0,21 \pm 0,1$ & $0,19 \pm 0,2$ & $0,20 \pm 0,2$ & 20 \\
\hline & COD & $\mathrm{mg} / \mathrm{L}$ & $6,41 \pm 0,002$ & $6,41 \pm 0,001$ & $6,6 \pm 0,3$ & - \\
\hline & Nitrat & $\mathrm{mg} / \mathrm{L}$ & $1,2 \pm 0,001$ & $1,55 \pm 0,002$ & $1,5 \pm 0,001$ & 0,008 \\
\hline & Fosfat & $\mathrm{mg} / \mathrm{L}$ & $0,02 \pm 0,002$ & $0,26 \pm 0,003$ & $<0,02 \pm 0,001$ & 0,015 \\
\hline & TOM & $\%$ & $33,06 \pm 0,7$ & $33,29 \pm 1,3$ & $31,77 \pm 0,9$ & - \\
\hline
\end{tabular}

Berdasarkan Tabel 2., nilai suhu pada tiap stasiun di perairan Senggarang Besar sebesar $29,9^{\circ} \mathrm{C}$ di stasiun $1,30,7^{\circ} \mathrm{C}$ di stasiun 2 dan $30,17^{\circ} \mathrm{C}$ di stasiun 3. Tidak terdapat perbedaan nilai yang signifikan pada setiap stasiun. Nilai suhu 
membatasi persebaran makrozoobentos, hal ini dipengaruhi oleh adanya faktor yang saling berhubungan, diantaranya DO (oksigen terlarut). Rendahnya oksigen terlarut dalam air dapat mempengaruhi metabolisme makrozoobentos. Perubahan suhu permukaan dapat berpengaruh terhadap proses fisika, kimia dan biologi di suatu perairan (Kusumaningtyas et al., 2014).

Berdasarkan Tabel 2., nilai kecerahan tiap stasiun di perairan Senggarang Besar berkisar 0,94 - 1,08 m, tinggi rendahnya nilai kecerahan diduga disebabkan adanya pengaruh masukan bahan organik dari aktivitas permukiman, bahan organik yang masuk ke dalam perairan menyebabkan sebagian cahaya sulit tertembus ke dalam perairan. Menurut Mustofa (2018), kecerahan perairan dipengaruhi oleh bahan-bahan yang tersuspensi, baik berupa lumpur, bahan organik, plankton dan mikroorganisme lainnya.

Salinitas merupakan jumlah berat semua garam yang terlarut dalam satu liter air atau gram per liter. Berdasarkan Tabel 2., nilai salinitas pada tiap stasiun berkisar 23,73 - 24,67\%o, Jika dibandingkan dengan penelitian yang dilakukan Azham et al., (2016) di Perairan Teluk Staring Kabupaten Konawe Selatan diperoleh nilai salinitas berkisar antara 2428\% , nilai salinitas tersebut tidak berbeda jauh dengan nilai yang diperoleh pada penelitian ini.

Berdasarkan Tabel 2., konsentrasi TSS pada tiap stasiun berkisar 4,31 - 5,16 mg/L, hal ini terjadi karena diduga masyarakat secara langsung atau tidak langsung membuang limbah rumah tangga ke perairan. Menurut Mustofa (2018) dan Hatijah et al. (2019), material padatan tersuspensi total juga mengandung bahan organik cukup tinggi yang dapat dijadikan salah satu faktor pendukung bagi kehidupan makrozoobentos.

Berdasarkan Tabel 2., nilai pH (derajat keasaman) pada tiap stasiun berkisar 7,23 - 7,29. Nilai pH yang diperoleh diduga terjadi karena adanya masukan bahan-bahan organik dari permukiman sehingga mempengaruhi konsentrasi pH tersebut. Menurut Pranoto (2017), adanya perbedaan nilai pH disebabkan oleh masukan limbah organik permukiman.

Berdasarkan Tabel 2., konsentrasi DO (oksigen terlarut) pada tiap stasiun berkisar 6,6 - 6,9 mg/L. Konsentrasi DO berbanding terbalik dengan parameter TSS, semakin tinggi nilai TSS maka semakin rendah konsentrasi DO. Hal tersebut disebabkan terganggunya intesitas cahaya yang masuk ke dalam perairan sehingga proses fotosintesis oleh mikroorganisme menjadi tidak optimal. Tingginya konsentrasi yang diperoleh pada stasiun 1 (6,9 mg/L) tersebut didukung oleh tingginya nilai TSS yang dengan nilai 5,16 mg/L.

Berdasarkan Tabel 2., konsentrasi BOD5 pada tiap stasiun berkisar 0,19 - 0,21 mg/L, konsentrasi tersebut tidak memiliki perbedaan yang jauh pada tiap stasiunnya. Hal ini diduga karena stasiun 2 yang memiliki ekosistem mangrove dan lamun, sehingga dapat menjaga kestabilan kondisi perairan. Konsentrasi BOD5 yang diperoleh pada tiap masih dapat menunjang kehidupan makrozoobentos berdasarkan Kepmen Lh No. 51 Tahun 2004.

Berdasarkan Tabel 2., konsentrasi COD pada tiap stasiun berkisar 6,4l - 6,6 mg/L. Kisaran konsentrasi tersebut menunjukkan bahwa wilayah perairan Senggarang Besar memiliki buangan limbah seperti plastik dan sejenisnya yang tidak dapat terurai dengan mudah. Menurut Herawati et al. (2017), tingginya konsentrasi COD dapat menunjukkan bahan organik yang ada di perairan lebih banyak dalam bentuk yang sukar didegradasi secara biologis

Berdasarkan Tabel 2., konsentrasi nitrat pada tiap stasiun berkisar 1,2 - 1,55 mg/L, konsentrasi tersebut menunjukkan bahwa terdapat buangan limbah organik ke dalam badan perairan sehingga mengendap dan tidak terencerkan oleh arus perairan. Konsentrasi nitrat yang diperoleh melewati ambang batas baku mutu berdasarkan Kepmen Lh No 51 Tahun 2004 yakni 0,008 mg/L.

Berdasarkan Tabel 2., konsentrasi fosfat pada tiap stasiun sebesar 0,02-0,26 mg/L, tinggi rendahnya konsentrasi fosfat dapat dipengaruhi oleh difusi fosfat dari substrat. Konsentrasi fosfat yang diperoleh pada stasiun 1 dan 2 menunjukkan perairan tersebut sangat subur, sehingga melampui ambang batas baku mutu berdasarkan Kepmen Lh No. 5l Tahun 2004 yakni 0,015 mg/L.

Berdasarkan Tabel 2., konsentrasi bahan organik substrat (TOM) perairan pada tiap stasiun berkisar 33,06 $33,29 \%$. Tinggi rendahnya bahan organik substrat diduga disebabkan oleh tingginya produksi serasah yang dihasilkan ekosistem lamun di kawasan stasiun 2 dan mengendap di dasar perairan. Menurut Riniatsih (2015), semakin tinggi kerapatan lamun, semakin banyak bahan organik yang terikat di dasar perairan.

\subsection{Substrat}

Hasil analisis jenis substrat secara keseluruhan disajikan pada Tabel 3. Hasil analisis jenis substrat dasar di perairan Senggarang Besar pada tiap stasiun memiliki karakteristik yang sama yakni berpasir. Kondisi substrat berpasir menunjukkan bahwa substrat jenis ini cukup baik berkorelasi terhadap sirkulasi air yang mengatur kelembaban dan mengsuplai oksigen serta nutrient. Menurut Mualiawan (2016), substrat yang berada di kawasan ekosistem mangrove memiliki kandungan oksigen dan ketersediaan nutrient yang cukup sebagai habitat makrozoobentos.

Tabel 3. Hasil Jenis Substrat

\begin{tabular}{cccc} 
Substrat & \multicolumn{3}{c}{ Stasiun } \\
Sand & $\mathbf{1}$ & $\mathbf{2}$ & $\mathbf{3}$ \\
Gravel & $100 \%$ & $100 \%$ & $100 \%$ \\
Tekstur & $0 \%$ & $0 \%$ & $0 \%$ \\
\hline
\end{tabular}




\subsection{Indeks Ekologi Makrozoobentos dan Substrat Perairan}

Makrozoobentos yang ditemukan pada tiap stasiun di Perairan Senggarang Besar terdiri dari 4 kelas, 13 famili dan 14 genus. Makrozoobentos memiliki tingkat toleransi terhadap perubahan kualitas perairan. Tingkat toleransi makrozoobentos terdiri dari toleran, intoleran dan fakultatif. Makrozoobentos yang ditemukan pada tiap stasiun disajikan pada Tabel 4 .

Tabel 4. Struktur Komunitas Makrozoobentos di Perairan Senggarang Besar

\begin{tabular}{|c|c|c|c|c|}
\hline Stasiun & Kelas & Famili & Spesies & Tingkat Toleransi \\
\hline 1 & $\begin{array}{l}\text { Bivalvia } \\
\text { Gastropoda }\end{array}$ & $\begin{array}{l}\text { Corbiculidae } \\
\text { Arcidae } \\
\text { Cerithiidae } \\
\text { Nassariidae }\end{array}$ & $\begin{array}{l}\text { Polymesoda erosa } \\
\text { Anadara granosa } \\
\text { Cerithium coralium } \\
\text { Nassarius olivaceus }\end{array}$ & Intoleran dan Fakultatif \\
\hline 2 & $\begin{array}{l}\text { Gastropoda } \\
\text { Polychaeta }\end{array}$ & $\begin{array}{l}\text { Luidiidae } \\
\text { Corbiculidae } \\
\text { Arcidae } \\
\text { Mactridae } \\
\text { Cerithiidae } \\
\text { Strombidae } \\
\text { Planaxidae } \\
\text { Neritidae } \\
\text { Ellobiidae } \\
\text { Capitellidae } \\
\end{array}$ & $\begin{array}{l}\text { Luidia columbia } \\
\text { Polymesoda erosa } \\
\text { Anadara granosa } \\
\text { Tapes literatus } \\
\text { Cerithium coralium } \\
\text { Canarium urceus } \\
\text { Planaxis sulcatus } \\
\text { Nerita ritena } \\
\text { Pythia scarabaeus } \\
\text { Capitella teleta } \\
\end{array}$ & Intoleran dan Fakultatif \\
\hline 3 & Gastropoda & $\begin{array}{l}\text { Cerithiidae } \\
\text { Potamididae } \\
\text { Muricidae }\end{array}$ & $\begin{array}{l}\text { Cerithium coralium } \\
\text { Pirenella sulcate } \\
\text { Terebralia sulcate } \\
\text { Semiricinula tissoti }\end{array}$ & Intoleran dan Fakultatif \\
\hline
\end{tabular}

Makrozoobentos yang teridentifikasi terdiri dari Polymesoda erosa dan Anadara granosa dari kelas bivalvia, serta Cerithium coralium dan Nassarius olivaceus dari kelas gastropoda. Gastropoda (Cerithium coralium, Nassarius olivaceus) yang ditemukan pada Stasiun 1 (kawasan permukiman) lebih dominan dibandingkan bivalvia (Polymesoda erosa, Anadara granosa), hal ini disebabkan makrozoobenthos dari kelas gastropoda dapat bertahan hidup dengan perubahan kondisi kualitas air khususnya salinitas perairan. Menurut Wahab et al. (2019), genus Cerithium sp. adalah genus dari populasi gastropoda yang hidupnya meliang dan merayap diantara tegakan lamun. Tingginya populasi gastropoda di suatu perairan di pengaruhi oleh habitat lamun, substrat dan parameter lingkungan. Lanjut Wahab et al. (2019), menjelaskan bahwa genus Cerithium sp. dari kelas gastropoda sangat menyukai salinitas yang optimum berkisar 24-31 ppt.

\subsection{Kepadatan Makrozoobentos}

Kepadatan makrozoobentos pada setiap stasiun pengamatan meliputi Stasiun 1, 2 dan 3 berkisar antara 206.667 $483.333 \mathrm{ind} / \mathrm{Ha}$. Kepadatan tertinggi terdapat pada Stasiun 2 (wilayah ekosistem mangrove) yaitu $483.333 \mathrm{ind} / \mathrm{Ha}$. Jenisjenis dari gastropoda, asteroidea dan bivalvia ini sangat mendominasi di Stasiun 2 dengan jumlah yang relatif banyak. Hal ini erat kaitannya dengan faktor habitat hidup kelompok makrozoobentos yaitu substrat. Menurut Rabiah (2017), karakteristik wilayah yang sangat dekat dengan garis pantai cenderung memiliki substrat berpasir sehingga menjadi habitat yang cocok bagi makrozoobentos.

Kepadatan terendah terdapat pada Stasiun 1 (wilayah permukiman) yaitu 206.667 ind/Ha. Jenis individu yang mendominasi pada wilayah ini adalah Cerithium sp. dari kelas gastropoda. Menurut Faiqoh et al. (2016), gastropoda memiliki daya tahan tubuh dan adaptasi cangkang yang keras, sehingga lebih memungkinkan untuk bertahan hidup dibandingkan jenis makrozoobentos lain.

\subsection{Indeks Ekologi (H', E, C) Makrozoobentos}

Keanekaragaman makrozoobentos di perairan Senggarang Besar dapat dilihat pada Tabel 5. Keanekaragaman (H') makrozoobentos tertinggi terdapat pada Stasiun 2 (wilayah ekosistem mangrove) dan Stasiun 3 (wilayah pasca tambang bauksit). Indeks keanekaragaman ( $\left.\mathrm{H}^{\prime}\right)$ terendah terdapat pada Stasiun 1 (wilayah permukiman) yaitu 0,93. Menurut Rijaluddin (2017), nilai keanekaragaman (H') yang rendah menggambarkan tingkat pencemaran berat oleh limbah domestik yang terakumulasi ke dalam badan perairan.

Indeks keseragaman (E) makrozoobentos pada tiap stasiun berkisar antara 0,67 - 0,94. Kondisi perairan Senggarang Besar masih dalam kondisi stabil sehingga komposisi penyebaran tiap jenis makrozoobentos cukup merata dan tidak ada jenis makrozoobentos yang mendominasi. Menurut Faiqoh et al. (2016), kestabilan suatu komunitas dapat digambarkan dengan tinggi rendahnya nilai indeks keseragaman (E) yang diperoleh.

Indeks dominansi (C) makrozoobentos pada Stasiun 2 (wilayah ekosistem mangrove) dan Stasiun 3 (wilayah pasca penambangan bauksit) memiliki tingkat dominansi yang rendah. Rendahnya tingkat dominansi disebabkan oleh 
terpenuhinya sumber nutrisi, sedangkan indeks dominasi (C) pada Stasiun 1 (wilayah permukiman) memiliki tingkat dominansi sedang. Hal ini diduga karena adanya masukan limbah akibat aktivitas masyarakat yang secara langsung atau tidak langsung masuk ke badan perairan. Menurut Zulfiandi et al. (2012) dan Normalasari et al. (2019), jika dalam suatu perairan ada jenis yang dominan maka perairan tersebut menunjukkan adanya tekanan ekologis yang menyebabkan kematian bagi organisme.

Tabel 5. Indeks Ekologi Makrozoobentos di Perairan Senggarang Besar

\begin{tabular}{cccc} 
Indeks & Stasiun & Nilai Indeks & Kategori \\
Keanekaragaman & 1 & 0,93 & Rendah \\
& 2 & 1,94 & Sedang \\
\multirow{3}{*}{ Keseragaman } & 3 & 1,3 & Sedang \\
& 1 & 0,67 & Sedang \\
\multirow{2}{*}{ Dominansi } & 2 & 0,83 & Tinggi \\
& 3 & 0,94 & Tinggi \\
& 1 & 0,52 & Sedang \\
& 2 & 0,19 & Rendah \\
\hline
\end{tabular}

\subsection{Famili Biotic Index (FBI)}

Nilai FBI makrozoobentos pada 3 stasiun pengamatan berkisar antara 5,6 - 7,12. Nilai FBI makrozoobentos tertinggi terdapat pada Stasiun 1 dan Stasiun 3 dengan nilai 7,12 dan 7 yang berarti kualitas air dalam kategori buruk dengan tingkat pencemaran terpolusi sangat banyak bahan organic, sedangkan nilai FBI terendah terdapat pada stasiun 2 dengan nilai 5,6 yang berarti kualitas air dalam kategori cukup dengan tingkat pencemaran terpolusi agak banyak bahan organik. Menurut Susilowati (2007), nilai FBI yang semakin besar menunjukkan kualitas air yang semakin buruk dan sebaliknya, apabila nilai FBI semakin rendah maka kualitas air semakin baik.

Tingginya nilai FBI di Stasiun 1 dan 3 disebabkan karena ditemukan Famili Potamidiidae dan Cerithiidae yang memiliki jumlah individu terbanyak. Famili Potamidiidae dan Cerithiidae merupakan kelompok dalam kelas gastropoda yang memiliki tingkat toleransi yang tinggi terhadap perubahan kondisi lingkungan. Menurut Rangan (2010), mengatakan bahwa Famili Potamidiidae dan Cerithiidae memiliki toleransi yang tinggi terhadap perubahan kondisi lingkungan akibat dari faktor-faktor fisik diluar ekosistem mangrove, sehingga organisme tersebut dapat bertahan hidup dan berkembang.

Rendahnya nilai FBI di stasiun 2 disebabkan karena ditemukannya jenis fakultatif seperti bivalvia dan gastropoda. Makrozoobentos jenis fakultatif seperti gastropoda memiliki individu lebih banyak serta memiliki mobilitas rendah dibandingkan jenis makrozoobentos lain, mengindikasikan perairan stasiun 2 terpolusi beberapa bahan organik. Menurut Dwitawati et al. (2015), makrozoobentos dari kelas gastropoda memiliki toleransi yang baik dengan kondisi perairan yang tercemar ringan sampai tercemar berat.

\section{SIMPULAN}

Dari hasil penelitian dan pembahasan dapat diambil kesimpulan bahwa: Makrozoobentos yang ditemukan dan diidentifikasi di Perairan Senggarang Besar berjumlah 13 famili dan 14 spesies dengan total kepadatan 906.666 ind/ha. Adapun jenis makrozoobentos yang ditemukan diantaranya Stasiun 1 (kawasan permukiman): Cerithium coralium, Anadara granosa, Nassarius olivaceus dan Polymesoda erosa. Dengan total kepadatan 206.667 ind/ha. Stasiun 2 (kawasan ekosistem mangrove): Anadara granosa, Capitella teleta, Canarium urceus, Cerithium coralium, Luidia columbia, Nerita ritena, Planaxis sulcatus, Polymesoda erosa, Pythia scarabaeus, dan Tapes literatus. Dengan total kepadatan 483.333 ind/ha. Stasiun 3 (kawasan pasca tambang bauksit): Cerithium coralium, Pirenella cingulata, Semiricinula tissoti dan Terebralia sulcata, dengan total kepadatan $263.333 \mathrm{ind} / \mathrm{ha}$.

Indeks keanekaragaman Stasiun $1(0,93)$ kategori rendah, Stasiun $2(1,94)$ dengan kategori sedang dan Stasiun $3(1,3)$ kategori sedang. Indeks keseragaman Stasiun $1(0,67)$ kategori sedang, Stasiun $2(0,83)$ kategori tinggi dan Stasiun 3 $(0,94)$ kategori tinggi. Indeks dominansi Stasiun $1(0,52)$ kategori sedang, Stasiun $2(0,19)$ kategori rendah dan Stasiun $3(0,29)$ kategori rendah.

Kualitas perairan berdasarkan makrozoobentos sebagai bioindikator perairan Senggarang Besar dengan perhitungan FBI pada Stasiun 1 kategori buruk dengan nilai 6,94, Stasiun 2 kategori cukup dengan nilai 5,6 dan Stasiun 3 dengan kategori buruk dengan nilai 7.

\section{REFERENSI}

Azham. S.R., Bahtiar., \& Ketjulan, R. (2016). Struktur Komunitas Makrozoobenthos pada Ekosistem Mangrove di Perairan Teluk Staring Kabupaten Konawe Selatan. Jurnal Manajemen Sumber Daya Perairan, 1(3): 249-260.

Dwitawati, D.A., Sulistyarsi, A., \& Widiyanto, J. (2015). Biomonitoring Kualitas Air Sungai Gandong Dengan Bioindikator Makroinvertebrata Sebagai Bahan Petunjuk Praktikum Pada Pokok Bahasan Pencemaran Lingkungan Smp Kelas Vii. Jurnal Florea, 2(1): 41-46. 
Efriningsih, R., Pustita, L., \& Ramses. (2016). Evaluasi Kualitas Lingkungan Perairan Pesisir di Sekitar TPA Telaga Punggur Kota Batam Berdasarkan Struktur Komunitas Makrozoobenthos. Jurnal Simbiosa, 5(1): 1-15.

Faiqoh, E., Hayati, H., \& Yudiastuti, K. (2016). Studi Komunitas Makrozoobenthos di Kawasan Hutan Mangrove Pulau Penyu, Tanjung Benoa, Bali. Journal of Marine and Aquatic Sciences, 2(1): 24-28.

Hatijah, S., Lestari, F., \& Kurniawan, D. (2019). Struktur komunitas gastropoda di Perairan Tanjung Siambang Kelurahan Dompak Kota Tanjungpinang, Provinsi Kepulauan Riau. Jurnal Pengelolaan Perairan, 2(2): 27-38.

Herawati, P., Barus, T.A., \& Wahyuningsih, H. (2017). Keanekaragaman Makrozoobentos dan Hubungannya dengan Penutupan Padang Lamun (Seagrass) di Perairan Mandailing Natal Sumatera Utara. Jurnal Biosains, 3(2): 66-72.

Kusumaningtyas, M.A., Bramawanto, R., Daulat, A., \& Pranowo, W.S. (2014). Kualitas Perairan Natuna pada Musim Transisi. Jurnal Depik, 3(1): 10-20.

Lubis, M.S., Basyuni, M., \& Suryanti, A. (2013). Keanekaragaman dan Kelimpahan Makrozoobentos di Sungai Naborsahan Kabupaten Toba Samosir Sumatera Utara. Jurnal Aquacoastmarine, 1(1): 1-8.

Megawati, C., Yusuf, M., \& Maslukah, L. (2014). Sebaran Kualitas Perairan Ditinjau dari Zat Hara, Oksigen Terlarut dan pH di Perairan Selat Bali Bagian Selatan. Journal of Oceanography, 3(2): 142-150.

Mualiawan, R., Dewiyanti, I., \& Karina, S. (2016). Struktur Komunitas Makrozoobenthos dan Kondisi Substrat pada Kawasan Mangrove di Pesisir Pulau Weh. Jurnal Ilmiah Mahasiswa Kelautan dan Perikanan Unsyiah, 1(2): 297-306.

Muhammad, F., Hidayat, J.W., \& Mukid, M.A. (2013). Aplikasi Bio-Ekologi Makrobenthos sebagai Bioindikator Tingkat Kesuburan Tambak. Jurnal Sains Matematika, 21(3): 75-83.

Musthofa, A., Muskananfola, M.R., \& Rudiyanti, S. (2014). Analisis Struktur Komunitas Makrozoobenthos sebagai Bioindikator Kualitas Perairan Sungai Wedung Kabupaten Demak. Diponegoro Journal of Maquares, 3(1): 81-88.

Mustofa, A. (2018). Pengaruh Total Padatan Tersuspensi Terhadap Biodiversitas Makrozoobentos Di Pantai Telukawur Kabupaten Jepara. Jurnal Disprotek, 9(1): 37-45.

Normalasari, Melani, W.R., \& Apriadi, T. (2019). Struktur Komunitas Gastropoda Di Perairan Air Kelubi Desa Resun Pesisir Kecamatan Lingga Utara Kabupaten Lingga. Jurnal Akuatiklestari, 2(2), 10-19. https://doi.org/10.31629/akuatiklestari.v2i2.993

Oktarina, A., \& Syamsudin, T.S. (2015). Keanekaragaman dan Distribusi Makrozoobentos di Perairan Lotik dan Lentik Kawasan Kampus Institut Teknologi Bandung, Jatinangor Sumedang, Jawa Barat. Jurnal Pros Biodiv Indon, 1(2): 227-235.

Pranoto, H. (2017). Studi Kelimpahan Dan Keanekaragaman Makrozoobentos di Perairan Bedagai, Kecamatan Tanjung Beringin Kabupaten Serdang Bedagai. Jurnal Biosains, 3(3): 125-130.

Rabiah., Kardhinata, E.H., \& Karim, A. (2017). Struktur Komunitas Makrozoobentos Di Kawasan Rehabilitasi Mangrove Dan Mangrove Alami Di Kampung Nipah Kabupaten Serdang Bedagai Sumatera Utara. Jurnal Biologi Lingkungan, Industri, Kesehatan, 3(2): 125-141.

Rangan, J.K. (2010). Inventarisasi Gastropoda Di Lantai Hutan Mangrove Desa Rap-Rap Kabupaten Minahasa Selatan Sulawesi Utara. Jurnal Perikanan dan Kelautan, 6(1): 63-66.

Ridwan, M., Fathoni, R., Fatihah, I., \& Pangestu, D.A. (2016). Struktur Komunitas Makrozoobenthos di Empat Muara Sungai Cagar Alam Pulau Dua, Serang, Banten. Al-Kauniyah Jurnal Biologi, 9(1): 57-65.

Rijaluddin, A.F., Wijayanti, F., \& Haryadi, J. (2017). Struktur Komunitas Makrozoobentos Di Situ Gintung, Situ Bungur Dan Situ Kuru, Ciputat Timur. Jurnal Teknologi Lingkungan, 18(2): 139-147.

Riniatsih, I. (2015). Distribusi Muatan Padatan Tersuspensi (MPT) di Padang Lamun di Perairan Teluk Awur dan Pantai Prawean Jepara. Jurnal Kelautan Tropis, 18(3): 121-126.

Sabar, M. (2016). Biodiversitas Dan Adaptasi Makrozoobentos di Perairan Mangrove. Jurnal Bioedukasi, 4(2): 529-539.

Saraswati, N.L.G.R.A., Arthana, I.W., \& Hendrawan, I.G. (2017). Analisis Kualitas Perairan pada Wilayah Perairan Pulau Serangan Bagian Utara Berdasarkan Baku Mutu Air Laut. Journal of Marine and Aquatic Sciences, 3(2): 163-170.

Susilowati, E. (2017). Struktur Komunitas Makrozoobentos sebagai Bioindikator Biologi Perairan di Hulu Sungai Cisadane Bogor. [Skripsi]. Institut Pertanian Bogor. Scientific Repository.

Wahab, I., Maduppa, H., Kawaroe, M., \& Nurafni. (2019). Analisis Kepadatan Makrozoobentos Pada Fase Bulan Berbeda di Lamun, Pulau Panggang, Kepualuan Seribu Jakarta. Jurnal Teknologi Perikanan dan Kelautan, 10(1): 93-107.

Zahidin, M. (2008). Kajian Kualitas Air Di Muara Sungai Pekalongan Ditinjau Dari Indeks Keanekaragaman Makrobenthos Dan Indeks Saprobitas Plankton. [Tesis]. Program Studi Magister Manajemen Sumberdaya Pantai. Universitas Diponegoro, Semarang.

Zulfiandi., Zainuri, M., \& Hartati, R. (2012). Struktur Komunitas Makrozoobentos di Perairan Pandansari Kecamatan Sayung Kabupaten Demak. Jurnal of Marine Research, 1(1): 62-66. 